\title{
Effects Of Some Locally Made Antiseptic Soaps on Some Skin Microbes
}

\section{Rabiu Lawan, Adam Idris}

Department of Microbiology and Biotechnology, Faculty of Science, Federal University Dutse, 7156, DutseJigawa State-Nigeria

\section{ABSTRACT}

\section{Article Info}

Volume 8, Issue 3

Page Number: 339-341

\section{Publication Issue :}

May-June-2021

\section{Article History}

Accepted : 03 June 2021

Published: 08 June 2021
The antimicrobial activity of some local antiseptic soaps against some isolated microorganisms (bacteria and fungi) were carried out by agar diffusion method. The highest zone of inhibition was recorded to be $3 \mathrm{~cm}$ at $100 \mathrm{mg} / \mathrm{ml}$ by $\mathrm{MK}$ antiseptic soap against E.coli, while IJB and S.T antiseptic soaps show no significant effect against the skin isolates of the bacteria Staphylococcus and Streptococcus. So also the antifungal activities of the three soaps were tested and the highest zone of inhibition was $5 \mathrm{~cm}$ at $100 \mathrm{mg} / \mathrm{ml}$ by IJB local antiseptic soap against Malessezia fur fur and Tricophyton spp, while there is less effect (generally less than $4 \mathrm{~cm}$ at $100 \mathrm{mg} / \mathrm{ml}, 50 \mathrm{mg} / \mathrm{ml}$ and $25 \mathrm{mg} / \mathrm{ml}$ ) of $\mathrm{MK}$ and S.T antiseptic soaps against the skin isolates of the fungi Malessezia furfur, Malessezia globossa, Microsporium spp and Tricophyton spp. This indicated that MK and IJB antiseptic soaps are potentially effective against bacteria and fungi respectively.

Keywords : Antimicrobial, Bacteria, Fungi, Inhibition, Antiseptic.

\section{INTRODUCTION}

Soap together with other cleansing agents have been in existence for a very long time. The discoveries of Archeologists during the trench of ancient Babylon disclose a soap like material in clay cylinders. The cylinder's inscriptions shows that fats were boiled with ashes, which is a procedure of making soaps. Likewise, a medical report from about 1500 B.C. revealed that Egyptians merge animal and vegetable oils with alkaline salts to make a soap-like material used for handling skin diseases, so also for washing (Hunt, 1999). Today, antisepsis/sanitization, decontamination, disinfection, and sterilization just to name a few, are expressions that describe methods of cleaning by either using detergents/soap or other cleaning agents (Hunt, 1999). Several cleaning agents are obtainable in the market, which are presented in different forms with clear formulations. P-chloro-mxylenol (PCMX/chloroxylenol), triclosan, and trichlorocarbamide which are the widely used antibacterial agent present in medicated soaps. These are commonly considered as preservatives unless the product is distinctly recognised as antiseptic, germicidal or antibacterial (Larson, 1988).

The first line of defense like scrubbing body or hands, particularly with soaps will be effective against bacteria and other pathogens that can cause colds, the flu, skin infections and even deadly communicable 
diseases (Kimel, 1996). Conceptually, numerious individuals think that an antimicrobial portion of soaps is capable of preventing communicable diseases. But now investigators show that too much of it may have the opposite effect-spreading infections/diseases instead of preventing them (Poole, 2002). Overutilization of medicated soaps might develop antimicrobial resistance and even making an individual more exposed to microbial attacks such as opportunistic skin infections (Levy, 2001).

This can be described by the fact that, periodically some of these antimicrobial consumer products could have inadequate quantities of antimicrobials. It appears to be more of a marketing phenomenon. Unfortunately, over time it may adversely affect the consumers, because overuse of these products can be ascribed to the development of drug-resistant microorganisms (Levy, 2001). This help to launch an evaluation of the antimicrobial impact of the so-called medicated soaps.

The continuous spread of dermatological infections has raised alarm in modern society. Other tried remedies such as the modern antiseptic soaps have proven effective but pose some disadvantages such as poor accessibility to the average populace due to their expensive price tags. Utilization of locally made antiseptic soaps is more economical and safer to use as they are derived from natural occurring substances hence generally acceptable.

\section{Locally Made Antiseptic Soaps as Remedy for Dermatological Infections}

Investigation of antibacterial action of African Black Soap on Escherichia coli, Staphylococcus aureus, and Pseudomonas aeruginosa was conducted using African Black Soap in different concentrations $(0.05 \mathrm{~g} / \mathrm{ml}, 0.01 \mathrm{~g} / \mathrm{ml}, 0.15 \mathrm{~g} / \mathrm{ml}$, and $0.20 \mathrm{~g} / \mathrm{ml})$. The ditch plate method was used to acquire the zone of inhibition at different concentrations of African Black
Soap on the test organisms (Varsha, 2016). The largest inhibition zone gotten was against $0.02 \mathrm{~g} / \mathrm{ml}$ concentration with the inhibition zone of $16 \mathrm{~mm}$ on $E$. coli, $P$. aeruginosa and $S$. aureus. This result revealed that African Black Soap manifested antibacterial activities against $S$. aureus, E. coli, and $P$. aeruginosa. And $0.15 \mathrm{~g} / \mathrm{ml}$ concentration was found to be the most effective on the $S$. aureus, $E$. coli, and $P$. aeruginosa. Therefore, local companies can enhance their product quality to comparable with traditional antiseptic soaps (Varsha, 2016).

Saba et al., 2009 have reported on liquid soaps, and their activity against pathogenic bacteria. The study sought to verify the antibacterial activity of different branded soaps against the bacteria that are regularly present within the environment. Detection of bacterial strains was done by the techniques of standard microbiology, which include biochemical testing, gram staining, and advanced identification by analytical profile index (Saba et al., 2009). Determination of the least inhibitory concentration and lowest bactericidal activity of strains was carried out by tube and micro titration method. Antibacterial soaps displayed better MIC in contrast with beauty soaps. The most resistant bacteria to all the soaps are Klebsiella pneumoniae and $P$. aeruginosa. It is clear and apparent that antibacterial soaps have the antibacterial means that can either inhibit or eliminate the bacterial cells. Even at high concentrations of soaps, it might be possible that some bacterial strains become resistant which leads to their survival (Saba et al., 2009).

\section{METHODS AND MATERIAL}

\subsection{Sample Collection}

Different samples of local antiseptic soap were purchased from Tarauni market, Yankaba market, and Sabon Gari market in Kano State. The batch number, expiry date and the presence or absence of the 
manufacturer's seal were noted (Mwambete and Lyombe, 2011).

\subsection{Preparation of Media}

All media were prepared according to the manufacturers' instruction. 65 grams of (SDA) sabouraud dextrose agar was dissolved in $1000 \mathrm{ml}$ of distilled water. Each media was boiled to dissolve the medium completely and was autoclaved at $121^{\circ} \mathrm{C}$ for 15 minutes and then it was dispensed into a sterile petri dishes to appropriate volume of $20 \mathrm{ml}$.

Twenty eight grams (28g) of (NA) nutrient agar was dissolved in $1000 \mathrm{ml}$ of distilled water. It was heated gently to dissolve the medium completely and was autoclaved at $121^{\circ} \mathrm{C}$ for 15 minutes and then a volume of $20 \mathrm{ml}$ was dispensed into sterile petri dishes.

\subsection{Isolation of Skin Pathogens}

Sterile swab sticks were used to collect samples from the skin of infected persons with various skin infections. Samples of skin swabs were collected from ringworm on the head, from groin area, and foot region (for the fungi), and pus (for the bacteria). The swab sticks used in the collection of fungal and bacterial isolates were inoculated on both (SDA) sabouraud dextrose agar and (NA) nutrient agar respectively using the streak method by streaking over the media. The (NA) plates were incubated at $37^{\circ} \mathrm{C}$ for 24 hours. While the (SDA) plates were incubated at $25^{\circ} \mathrm{C}$ for 3-5days (Monica, 2006).

\subsection{Identification of Isolates}

Bacterial isolates were identified using gram staining and biochemical test as described in Monica (2006).While fungal isolates were identified both macroscopically and microscopically according to the method described in Monica (2006).

\subsection{Biochemical Analysis of the Test Organism}

Catalase test; the main objective of this test was to know the presence of the unknown catalase enzyme in the isolates.
One inoculum was picked from a plate culture and placed on a slide. Few drops of hydrogen peroxide $\left(\mathrm{H}_{2} \mathrm{O}_{2}\right)$ was added to it, bubbles were formed immediately which indicated a positive result.

Oxidase test: the main objective of this test was to know the presence of the enzyme oxidase on the unknown isolates.

A good amount of inoculum (already incubated and grown) from a culture plate was picked and placed on a piece of filter paper. One drop of the oxidase reagent was added onto the filter paper, and within the first 20 seconds, no blue -purple colour was formed and this indicates a negative result.

Coagulase test: the main objective of this test was to identify the presence of the enzyme coagulase. The slide method of Cheesbrough (2005) was used. A drop of saline on two separate spots was placed on a greasefree slide. Then a speck of growth of the test organism was picked with sterile wire loop and emulsified to form a smear. To one spot, a drop of plasma was added, while to the other a drop of saline was added. The treated mixtures were mixed thoroughly by rocking. Coagulation was an indication of positive test in the slide. The presence of clotting indicates positive test for $S$. aureus. This test was based on the capability of the test organism to produce coagulase enzyme which causes the coagulation of human plasma.

Indole test: A peptone broth was inoculated with the test organism and incubated at $37^{\circ} \mathrm{C}$ for $24-48$ hours. $0.5 \mathrm{ml}$ of kovac's reagent was added and agitated gently.

The upper layer of the liquid was examined immediately; a red colour was formed which indicated a positive result.

\subsection{Sensitivity Testing of Soaps Using Agar Diffusion Method}

The method that was used is agar diffusion method, and the soap solutions were diluted to different 
concentrations, that is $100 \mathrm{mg} / \mathrm{ml}, 50 \mathrm{mg} / \mathrm{ml}$ and $25 \mathrm{mg} / \mathrm{ml}$ respectively from the stock solution (by dissolving 1 gram of soap into $9 \mathrm{ml}$ of distilled water) of the soap using two fold serial dilution. One gram (1g) of soap was added to $9 \mathrm{ml}$ of distilled water to make a stock solution. Then $5 \mathrm{ml}$ of the stock solution was added to the first test tube containing $5 \mathrm{ml}$ of distilled water making it $100 \mathrm{mg} / \mathrm{ml}$, then $5 \mathrm{ml}$ was removed from the first test tube and then was dropped to the second test tube making $50 \mathrm{mg} / \mathrm{ml}$, and also $5 \mathrm{ml}$ was removed from the second test tube and then was added to the third test tube containing $5 \mathrm{ml}$ of distilled water making it $25 \mathrm{mg} / \mathrm{ml}$. Finally, from the third test tube $5 \mathrm{ml}$ was removed and discarded. Discs made with filter papers were sterilized and then soaked into the solutions of varying concentrations. Then the discs containing the different concentration were placed onto the agar (sabouraud dextrose agar and nutrient agar) seeded with the test organism. They were incubated at $37^{\circ} \mathrm{C}$ and $25^{\circ} \mathrm{C}$ for 24 hours respectively. The diameter of clearance (i.e the zone of inhibition) around the plates were noted and recorded (Abbas et al., 2016).

\section{RESULTS AND DISCUSSION}

A total of 40 samples collected were screened for Isolation and the identification of some bacterial and fungal isolates.

\subsection{Isolation of Bacteria}

A total of 20 samples were subjected to bacteriological examinations. All the samples showed growth on solid media (nutrient agar). Most bacterial isolates were identified based on colony morphology, gram reaction, as well as biochemical test. Sample 1, 2, 9, 3, $5,7,12,13,14$, and 15 were found to be oval in shape, and gram positive in reaction. They were presumed to be Staphylococcus aureus. Sample 4, 8, 11, 17, and 19 were identified to be clustered cocci and gram positive in reaction, hence they were presumed to be Streptococcus spp. Sample 6, 10, 16, 18, and 20 were identified to be rod shaped bacilli and were presumed to be E. coli.

\subsection{Biochemical Identification}

Isolates that were gram positive cocci, catalase and coagulase positive were characterized as $S$. aureus. Streptococcus were identified by being catalase, coagulase, and indole negative. Isolates that were gram negative bacilli, and indole positive were characterized to be E.coli.

\subsection{Isolation and Identification of Fungi}

Twenty (20) samples were subjected to analysis for the isolation and identification of fungi. All the samples grow on solid agar (SDA). The fungal species were identified on the basis of colony morphology and microscopic examination.

Samples like sample 1 and 4 were seen as spherical, creamy in color with bottle shaped under the microscope, hence they were presumed to be fungi of the genus Malassezia fur fur. So also samples like sample 2 and 18 were seen to have smooth macro and micro conidia borne directly under hyphae, therefore Tricophyton spp were presumed.

Some of the samples like sample 14 and 16 were seen to have whooly and powdery colonies, and the colony diameter at the range of $7 \mathrm{~cm}$, hence Microsporium spp were presumed. Sample 12, 15, 17, and 20 were seen as milky in color, cocci in shape with bottle neck, so Malassezia globossa were presumed.

\subsection{Antimicrobial Assay}

Different concentrations of the 3 local antiseptic soaps labelled as MK, IJB, and ST i.e $100 \mathrm{mg} / \mathrm{ml}, 50 \mathrm{mg} / \mathrm{ml}$ and $25 \mathrm{mg} / \mathrm{ml}$ were added into culture of bacteria using the agar disc diffusion method. The plates were incubated overnight at $37^{\circ} \mathrm{C}$. Zones of inhibitions were measured and the result is shown below (Table $1)$. 
Table 1 : Bacterial Isolates with Antiseptic Soaps and Their Zones of Inhibitions

\begin{tabular}{|c|c|c|c|c|}
\hline \multirow[t]{3}{*}{ Bacterial isolates } & \multirow[t]{3}{*}{ Antiseptic soaps } & \multicolumn{3}{|c|}{ Zones of inhibition $(\mathrm{cm})$} \\
\hline & & \multicolumn{3}{|c|}{ Concentrations (mg/ml) } \\
\hline & & 100 & 50 & 25 \\
\hline Staphylococcus spp & MK & 0 & 2 & 0 \\
\hline Staphylococcus spp & IJB & 0 & 0 & 0 \\
\hline Staphylococcus spp & ST & 0 & 0 & 3 \\
\hline Streptococcus spp & MK & 0 & 3 & 1 \\
\hline Streptococcus spp & IJB & 2 & 0 & 0 \\
\hline Streptococcus spp & ST & 0 & 0 & 1 \\
\hline E. coli & MK & 3 & 1 & 0 \\
\hline E. coli & IJB & 2 & 2 & 0 \\
\hline E. coli & ST & 2 & 1 & 1 \\
\hline
\end{tabular}

Different concentrations of the 3 local antiseptic soaps labelled as MK, IJB, and ST i.e 100mg/ml, $50 \mathrm{mg} / \mathrm{ml}$ and $25 \mathrm{mg} / \mathrm{ml}$ were added into culture of fungi using the agar disc diffusion method. The plates were incubated $25^{\circ} \mathrm{C}$ for 3-5 days. Zones of inhibitions were measured and the result is shown below (Table 2).

Table 2: Fungal Isolates with Antiseptic Soaps and Their Zones of Inhibitions

Fungal isolates

Antiseptic soaps

MK

Malassezia furfur
100

\section{Zones of inhibition (cm)}

Concentrations (mg/ml)

$\begin{array}{lll}100 & 50 & 25\end{array}$

$\begin{array}{lll}3 & 1 & 1\end{array}$




\begin{tabular}{llccc} 
Malassezia furfur & IJB & 5 & 4 & 3 \\
Malassezia furfur & ST & 0 & 2 & 0 \\
Tricophyton spp & MK & 2 & 0 & 3 \\
Tricophyton spp & IJB & 5 & 3 & 1 \\
Tricophyton spp & ST & 1 & 3 & 1 \\
Microsporium spp & MK & 3 & 1 & 2 \\
Microsporium spp & IJB & 4 & 3 & 0 \\
Microsporium spp & ST & 0 & 2 & 1 \\
Malasseezia globosa & & & 2 \\
Malasseezia globosa & MK & 0 & 4 & 1 \\
Malasseezia globosa & IJB & 4 & 3 & 1 \\
\hline
\end{tabular}

\section{DISCUSSION}

In general soaps are used for cleaning purposes and in order to remove dust and microbes present on the surface of skin. The choice of soap varies from person to person but it should not affect the sensitive skin and it should be effective against disease causing microbes present on the skin. The present research investigation was carried out to determine the antimicrobial activity of local antiseptic soaps, Mekako, S.T, and Ijebu against some isolated microorganisms (bacteria and fungi). This study suggests that antiseptic soaps were more effective against fungi than bacterial isolates. A similar work of Hunt (1999) showed that plain soaps also possessed antibacterial activity although lesser than that of antimicrobial soaps. Varsha (2016) studied the hand washing with antiseptic soaps removes millions of microorganisms.
Most of the research has been focused on hand washing and hand disinfectants for personnel in health care settings where patients are immune compromised and are at high risk. Kimel (1996) indicated that hand washing with bar soap reduced bacterial population. Levy (2001) in response to the Association for Professionals in Infection Control and Epidemiology (APIC) emphasized the use of antimicrobial household products.

Results obtained from the experimental data revealed that most of the studied antiseptic soaps have antimicrobial activity, though to varying degrees as indicated by the inhibition of the growth pattern of the isolates. Varied levels of effectiveness by soaps were observed against the isolated skin flora pathogens.

The growth of the isolated bacteria in Staphylococcus was inhibited by Mekako local anti-septic soap at concentration of $50 \mathrm{mg} / \mathrm{ml}$ with $2 \mathrm{~cm}$ zone of inhibition where Ijebu anti septic soap was found to 
be of no effect against Staphylococcus. S.T antiseptic soap has the highest inhibition at $25 \mathrm{mg} / \mathrm{ml}$ with $3 \mathrm{~cm}$ zone of inhibition. The growth of Streptococcus isolates was inhibited by mekako local antiseptic soap at $50 \mathrm{mg} / \mathrm{ml}$ by $3 \mathrm{~cm}$ zone of inhibition. Ijebu local antiseptic soap was found to inhibit the growth of Streptococcus at $100 \mathrm{ml} / \mathrm{mg}$ by $2 \mathrm{~cm}$ zone of inhibition. S.T antiseptic soap inhibits the growth of Streptococcus by only $1 \mathrm{~cm}$ zone of inhibition at $25 \mathrm{mg} / \mathrm{ml}$.

The growth of E.coli was found to be inhibited at $100 \mathrm{mg} / \mathrm{ml}$ of Mekako anti septic soap by $3 \mathrm{~cm}$ zone of inhibition; whereas Ijebu antiseptic soap inhibit the growth of E.coli by $2 \mathrm{~cm}$ zone of inhibition at $100 \mathrm{mg} / \mathrm{ml}$ and $50 \mathrm{mg} / \mathrm{ml}$. S.T antiseptic soap have inhibitory rate of $2 \mathrm{~cm}$ at $100 \mathrm{mg} / \mathrm{ml}$.

The result of this present study is similar to (Varsha, 2016) who reported the anti-bacterial activity of African black soap Staphylococcus aureus and Escherichia coli with a highest zone of inhibition of $16 \mathrm{~mm}$ at $0.02 \mathrm{~g} / \mathrm{ml}$.

(Abbas et al., 2016) reported that medicated soap available in local market of rawpindi, the bacterial strain of Escherichia coli, Staphylococcus aureus and Salmonella typhi were treated with different concentration of $50 \mathrm{mg} / \mathrm{ml}, 100 \mathrm{mg} / \mathrm{ml}$ and $150 \mathrm{mg} / \mathrm{ml}$ shows a highest zone of inhibition.

Antimicrobial activity of different antiseptic and herbal market soaps were checked against isolates of bacteria that are present on the surface of the skin like Staphylococcus aureus, Bacillus subtilis, Escherichia coli and Pseudomonas aeruginosa using the method of agar disc diffusion (Varsha, 2016). Different microorganisms are placed on the skin surface from the dust present in external environment which causes infection. Antimicrobial activities of different soaps on such micro flora or pathogens were studied. The results obtained show that among the antiseptic soaps, the one that shows highest competency was Lifebuoy Plus and Dettol soaps against Gram positive isolates but in Gram negative isolates Dettol and Savlon had maximum bactericidal activity. In Herbal soaps Neem followed by Aloe Vera were found to be most striking with all isolates as seen in Haldi Chandan soap. The most resistant isolate to all soaps in the study was found to be Pseudomonas aeruginosa (Varsha, 2016).

Hands are exposed openly to a lot of materials which consist of dirt contacted during personal hygiene (Johnson et al., 2002). Bacteria are placed on skin from external sources causing variety of diseases (Vicca, 1999). Sanitizing hands with antibacterial hand washes terminates the dispersal of bacteria or loose transient flora, forbidding cross infections (Jabbar, 2010). Phenol was used as control to measure up its effectiveness with liquid soaps. In the liquid soaps list, safeguard was found with highest efficacy in terms of its MIC against $S$. aureus and $E$. coli while Johnson and Johnson baby liquid soap had maximum activity against various microorganisms (Ahmad et al., 2009).

Mekako was found to inhibit the growth of fungi Malassezia furfur at $100 \mathrm{mg} / \mathrm{ml}$ by $3 \mathrm{~cm}$ zone of inhibition. It was discovered and observed that the highest zone of inhibition of Malassezia fur fur was found to be at $100 \mathrm{mg} / \mathrm{ml}$ of Ijebu antiseptic soap with the inhibition zone of $5 \mathrm{~cm}$.

So also, Tricophyton spp growth was inhibited the most at $100 \mathrm{mg} / \mathrm{ml}$ by a zone of inhibition of $5 \mathrm{~cm}$ using Ijebu antiseptic soap. Microsporium spp growth was inhibited by Ijebu antiseptic soap at $100 \mathrm{mg} / \mathrm{ml}$ by $4 \mathrm{~cm}$ zone of inhibition. Malassezia globossa growth was also found to be inhibited at $100 \mathrm{mg} / \mathrm{ml}$ by a zone of inhition of $4 \mathrm{~cm}$ using Ijebu antiseptic soap. While the growth of fungal isolate of Malassezia furfur and Microsporium spp was not inhibited well by ST antiseptic soap.

\section{IV.CONCLUSION}

From this work it is seen that the growth of bacteria in most of the samples were inhibited by Mekako local anti-septic soap. On the other hand there is no significant response to the other local anti-septic 
soaps such as Ijebu local anti-septic soap and S.T anti-septic soap. On the other hand, the growth of fungi in most of the samples was inhibited by Ijebu local anti-septic soap. There is no significant response to the other two local anti-septic soaps i.e Mekako anti septic soap and S.T anti septic soap. This is to conclude that Mekako local anti-septic soap was effective as an anti-bacterial agent against the isolated bacteria. While Ijebu local anti-septic soap was effective as an anti-fungal agent against the isolated fungi.

\section{REFERENCES}

[1]. Ahmad, A. Riaz, S. Hasnain, S. (2009). Antibacterial activity of soaps against daily encountered bacteria. African. Journal of Biotechnology 93(8): 1431-1436.

[2]. Hunt, J.A. (1999). A short history of soap. International Journal of Pharmacy 263(65): 985989.

[3]. Jabbar, S.A. (2010). Comparative susceptibility of resident and transient hand bacteria to parachloro-meta-xylenol and triclosan. Journal of Applied Microbiology 93(93): 336-344.

[4]. Johnson, S.A. Goddard, P.A. Illife, C. Timmins, B. Rickard, A.H. Robson, and Handley, P.S. (2002). Comparative susceptibility of resident and transient hand bacteria to para-chloro-metaxylenol and triclosan. . Journal of Applied Microbiology 93(93): 336-344.

[5]. Kimel, L.S. (1996). Hand washing education can decrease illness absenteeism. Journal of School Nursing 22(12): 14-18.

[6]. Kimel, L.S. (1996). Hand washing education can decrease illness absenteeism. Journal of School Nursing 22(12): 14-18.

[7]. Larson, E. (1988). A causal link between hand washing and risk of infection; examining the evidence. Journal of Infection Control of Hospital Epidemiology 11(9): 28-36.

[8]. Larson, E. (1988). Apic guideline for infection control practice. Guideline for use of topical antimicrobial agents. American Journal of Infection Control 32(16): 253-266.

[9]. Larson, E., (1999). Skin hygiene and infection prevention: more of the same or different approaches. Journal for clinical infectious diseases 76(29): 1287-1294. 10.1086/313468.

[10]. Levy, S.B. (2001). Antibacterial household products. Cause for Concern 85(7): 512-515.

[11]. Mirmirani, P., Maurer, T.A., Berger, T.G., Sands, L.P., and Chren, M.M. (2002). Skin related quality of life in HIV-infected patients on highly active anti-retroviral therapy. Journal of Cutaneous Medicine and Surgery 6(6): 10-15.

[12]. Mwambete, K.D. Lyombe, F. (2011). Antimicrobial activity of medicated soaps commonly used by Dar es Salaam residents in Tanzania. International Journal of Pharmaceutical Sciences 73(1): 92-98.

[13]. P.S. (2002). Comparative susceptibility of resident and transient hand bacteria to para-chloro-metaxylenol and triclosan. Journal of Applied Microbiology 93(7): 216-276.

[14]. Poople, K. (2002). Mechanisms of bacterial biocide and antibiotic resistance. Journal of Applied Microbiology 92(7): 55-64.

[15]. Varsha, M.C. (2016). Studies on antimicrobial activity of antiseptic soaps and herbal soaps against selected human pathogens. Journal of Scientific and Innovative Research 5(6): 201-204.

[16]. Vicca, A.F. (1999). Nursing staff work load as a determinant of methicilin resistance. Journal of Hospital Infections 43(2): 109-113.

[17]. World Bank. (2002). World Development Indicators Washington, DC: World Bank.

\section{Cite this article as :}

Rabiu Lawan, Adam Idris, " Effects Of Some Locally Made Antiseptic Soaps on Some Skin Microbes, International Journal of Scientific Research in Science, Engineering and Technology(IJSRSET), Print ISSN : 2395-1990, Online ISSN : 2394-4099, Volume 8, Issue 3, pp.339-341, May-June-2021. Available at doi $\quad$ : https://doi.org/10.32628/IJSRSET218357 Journal URL : https://ijsrset.com/IJSRSET218357 